\title{
Domestication or Encapsulation? Developing Coffee Culture Among Indonesia Middle-Class Income
}

\author{
Yayuk Yuliati ${ }^{*}$ and Mangku Purnomo ${ }^{2}$ \\ 1 Socio-economics Department, Faculty of Agriculture Brawijaya University; y.yuliati@ub.ac.id (Y.Y.) \\ 2 Socio-economics Department, Faculty of Agriculture Brawijaya University; mangku@ub.ac.id (M.P.) \\ * Correspondence: y.yuliati@ub.ac.id; Tel.: (+62 0341 580054) (Y.Y.)
}

\begin{abstract}
This article is an anthropology study on how western-style coffee culture influences Indonesian coffee culture and eventually develops a new localized coffee culture. Immense development of such worldwide coffee franchise as Starbucks affects local community's coffee culture, particularly the middle class. This new wave is considered as an alternative lifestyle for those who are consumptive and seeking for leisure, dynamics, and identity. Broader than just the process of domestication or creolization, Indonesian new coffee culture has an element of "soft countering to" western coffee culture even though it still embraces some parts of the western styles. This phenomenon is referred to by the writer as the cultural encapsulation process or the process of substantial cultural resistance by drawing a line between the two coffee cultures with the intention of taking merely compatible elements.
\end{abstract}

Keywords: coffee culture, domestication, creolization, encapsulation, and middle class

\section{Introduction}

Research on coffee production and consumption as well as the accompanying cultures is exhibited in Latin America, Eropa, and America or several areas in Africa. On the other hand, Asia which production and its coffee consumption continued to increase has received less attention [1][3]. Coffee was originally an Arab monopoly, a European colonial product, the symbol of sustenance in Latin America state, and currently a globally produced multinational commodity (Talbot, 1997; Tucker, 2012). Coffee has become a global commodity since the beginning of its discovery; therefore, it is not surprising that the variation of coffee culture is also very diverse between regions. Currently, there has been a huge expansion of the Starbucks-style coffee culture all over the world and it became part of the consumptive urban lifestyle. Kjeldgaard and Ostberg, (2007) mention that the expansion of coffee shop is the factor of the globalization of consumer culture, growing an appreciation of highquality coffee, and the public's eager acceptance of casual spots to study, relaxes, socialize, or pick up an energizing drink.

The rise of a new cultural style in the consumer culture discipline is known as the concept of creolization - the robust concept on consumer culture in figuring how the local and global food culture built new culture in which different cultural meanings are fused to create new forms [6], [7]. Sidbury (2007) describes the cultural transformation of African slaves in America as a process of creolization-a unique blend that reflects the two dimensions of the process of colonization as well as the process of resistance. Developed from a concept that explains cultural transformation in the colony, intensive creolization is used to analyze the formation of new cultural identities due to contact with outside cultures including consumer culture. Steward (2016) [8] explicitly explains how the concept of creolization is used to analyze the cultural transformation process in various colony 
regions of the world, not as a cultural resistance, but rather as an effort to adapt the colonial culture with the local people or transcultural mixing until a new cultural identity is born.

Creolization is no longer merely a reference to the study of New World cultures of the Caribbean and Latin American creole societies, but it has become a universal process that could occur where cultures encounter one another [9]-[13]. The concept of creolization extends to various themes of study ranging from architecture, art, custom ceremonies, as well as lifestyles and foods including consumption culture. In regards to consumer culture, food and consumption, creolization is a localized meaning of global product in order to be easily accepted by emerging markets that are usually more active than passive, and actively negotiate the consumption process. Food preparation, presentation, and surrounding culture are aspects that are significantly experiencing the rapid creolization process [14].

A number of researchers also describe the phenomenon as "glocalization", proposing the concept of "glocalization" to explain the process of how a global culture is intelligently given a local meaning to a completely new culture. Take media glocalization as an example, glocalization refers to methods in which media companies localize their content by infusing design, narratives, and content using local elements [15], [16]. It exhibits glocalization possesses a more active role in local culture to interpret new culture as a dialectical process rather than just cultural fusion or hybridity culture. If creolization is more focused on intercultural fusion, glocalization follows the co-existence theory in which global and local cultures develop together therefore universalizing and particularizing tendencies occur simultaneously [17]-[19].

Should creolization and glocalization are more of a cultural fusion process, then other concepts emerge which view new cultures adapted to local environments such as domestication-a local cultural endeavor to dominate or associate an external culture with a new culture. Caldwell (2004) intelligently describes the process of "blurring / blurting" the boundaries of cultural identity from the outside by associating the new culture as part of the local culture. For example, Mc Donald's restaurant, the company's intelligent operators were able to build the image that Mc Donald was a food in line with the "Muscovit" culture, by obscuring the impression that Mc Donald was an American food culturally imprinted as the eternal enemy of the Russian nation [20].

What is the coffee culture in Indonesia, particularly one developed by local coffee shops as a process of creolization or domestication? McDonald in Moscow in [20] research, is trying to instill the value that McDonald is a Moscow-spirited food by "blurring" the wall between American and local food. But in the case of coffee consumers, they are building the value that the coffee a la Starbucks is a new way of life. The knowledge of coffee spreads to the community where the store is the center of information dissemination of various varieties of coffee, the origin of coffee, the way of processing coffee as well as the value of "resistance" to the practice of instant coffee company monopoly including Starbucks. There are three processes on how global culture influences local culture, namely Ritzer's hegemonic pattern with Macdonalisation, then Robin Cohen's Creolization with cross culture concept and Gidoni's flexible cultural construction [21].

Taking a case of coffee culture in Japan, Grinshpun (2014) sees the new culture being formed as a more dynamic process in which locality is an active agency capable of building a new cultural form as a result of reciprocity rather than conquest or hegemony of ansich. In line with Grinshpun, Indonesia will be more likely to follow the third pattern let alone culturally cultivated coffee and become part of the local culture although it tends to be monotonous and does not develop into a 
profitable business as it is in the country. At the same time, local coffee shop faciliting interaction between baristas and consumers in building a coffee learning community that can increase consumer awareness on the ethic aspect, therefore, it becomes consumer consideration. Let alone some of them are specific "connoisseurship" which has a special tendency [22], [23].

Considering the development of coffee culture especially among Indonesian middle class, the third pattern is relatively in line although it has some differences. More precisely, there has been a process of affirming the value and local coffee culture in coffee business, but the proprietors selectively induce selective culture and new coffee techniques from the west. It is almost identical to the theory of encapsulation in counseling techniques in which counselors create/engineer the environment and a comfortable atmosphere for learners so that they can grow well by limiting outside influences and strengthening student's character [24], [25]. Thus, the coffee community constructed a kind of "permeable membrane" that limited the western coffee culture to change the local coffee culture but still be penetrated for certain values. In politics, cultural encapsulation is used in analyzing the ruling strategy for managing conflict spaces with small groups through policies limiting their movement in developing their ideology while providing special privileges to groups as to deter them from revolting [26].

In the context of coffee culture, local coffee businessmen born from the network of coffee lovers and middle class create their own environment by selectively take value from outside factors which are considered useful to maintain local culture. They become independent entities and develop localstyle coffee shops and tend to be closed in managing their business but selectively adopt technology and knowledge about coffee from outside factors. What are the consequences of local coffee culture and business if cultural developments follow the pattern of encapsulation? It is extremely difficult for business and local coffee culture to develop into a strong networking business system because it is difficult to replicate. Therefore, I present my thesis after observing that local coffee houses were unable to open a branch despite having many customers and financial ability. To describe how a new coffee culture is developed among the Indonesian middle classes, we divide this paper into three main points: cultivating the new coffee culture and "starbuckization" process, followed by the resistance of local business actors on the "starbuckization" process, and how the local coffee culture shows its identity by building network between consumers and with farmers.

\section{Materials and Methods}

Our first introduction to coffee community took place in 2012 when we were a consultant for the project where the World Bank, the Indonesia Ministry of Agriculture and FEATI (Farmer Empowerment through Agricultural Technology and Information) worked together. This project is an effort to resuscitate agricultural extension program in Indonesia after a 20-year hiatus in postreformation. When we participated in the project, we met young educated people who were interested in coffee, and had concern towards the fate of monopolized coffee farmers. They often stayed at farmhouses for a week or two to learn the ins and outs of coffee bean, starting from cultivation, harvest dates, brewing to how to start a coffee business in a city. We were not interested in coffee yet since my main focus was assisting the banana farmers. However, we always wrote down some information about it. Farmer welfare and coffee price are depending on the traders, and sorrowful stories of the farmer having to wait one year for harvest dates have always been the topics of our nightly discussion. Farmers' conversation we overheard in the food stalls about how the 
traders manipulated price of their coffee was something that later attracted us to investigate further into coffee culture.

2 years into the project going on in 2014, coffee started to attract my interest. The number of young people and their intensity to visit coffee farmers were getting higher especially during harvest dates. They even started to formally introduce coffee culture to the farmers through an event facilitated by village government. After being confirmed, they were coffee shop owners of which located in the city. Some of these coffee shop owners were still university students. Coffee bean transaction with the owner of those coffee shops was getting more frequent, and several farmers even had informal contact with some of the owners to provide coffee bean in a particular amount for next season. From that moment, we became interested in coffee commodity. Another contact with the community was intensively performed after getting a 4-year research fund from the Ministry of Research and Higher Education. Once my contract with the World Bank project ended, we started the study on coffee community development systematically. The study took place between 2014 and 2018. We conducted more intensive observation with more accurate and designed methodology both for coffee farmers and coffee shop networking in four middle and big cities, Malang, Jakarta, Jogjakarta, and Surabaya ${ }^{1}$.

In-depth interviews were conducted with coffee lovers, farmers, coffee shop owners, and coffee researchers (both cultivation experts and coffee business researchers). Coffee lovers contributed idea of how the starbuck-style coffee process grows and develops into Indonesia, how it spreads and how far it affects local coffee culture. Data on the development of most consumed local coffee types and the tendency of the last ten years of community consumption patterns are obtained through in-depth interviews with coffee shop owners. We conducted cross-checks up to the farmer level to prove whether the coffee shop owners and coffee lovers cooperate with the farmers or not. In particular we also conducted in-depth interviews with senior coffee researchers both at universities and coffee research institutions to get an idea of how the dynamics of the changing culture of local coffee occurred.

Qualitative content analysis was used to analyze the process of penetrating western-style coffee culture to illustrate emerging patterns both adoption and rejection, including mixing or modification processes, both presentation techniques and coffee shop atmosphere creation. We also use theme analysis to strengthen analytical content accompanied by a historical approach because the formation of coffee culture is a gradual process in a certain period of time. This analysis is also very useful to describe the process of forming new values created by the coffee shop community in building identities different from the international network stores, both as a form of resistance and adoption. The efforts of the actors in building identity which later became a distinction between them and transnational stores fully used theme analysis, including the creation of special terms as an alternative to the maintream term used by transnational stores.

\section{Results}

\subsection{Cultivating New Coffee Culture}

\footnotetext{
1 The four cities are selected as the setting of the study because they have their own characteristics. Jakarta is the capital city known as the center of the national business while Jogjakarta is well-known for its tourism. Malang is a university city and Surabaya is the center for the national industry. The number of local coffee shops has increased sharply in these cities in the last five years. Having interviewed the local coffee organization in the four cities, there are more than 450 coffee shops in Jakarta, 230 in Jogjakarta, 230 in Malang and 320 in Surabaya.
} 
Initially, a new culture of drinking coffee in Indonesia was lifestyle introduced by coffee lovers individually as an impact of coffee commodification process, one the modifier commodities of the world. Indonesia is the leading coffee producer in the world but then coffee drinking culture performed by local community was still basic with totally undeveloped service variation and kind of processing2. In contrast to the development of coffee in the west, especially Europe and America, where coffee, tea, and chocolate become integrated with culture, in Indonesia coffee is a complimentary drink with monotonous service variation. The slow development of coffee culture in coffee-producing countries is believed to be a colonial strategy to keep coffee for themselves while the local market should be satisfied with low quality coffee to avoid competition with the locals [27][29].

Coffee is able to change face of economics face and culture of the world from the era of colonial to modern economics [5], [30], [31]. Slowly but surely the new culture of drinking coffee increases its status from ancient habit to the symbol of new lifestyle among the middle class in Indonesia. Until today, drinking coffee is identified with ancient habit and not common for young people let alone women, although it is extremely popular for Indonesian. Taste in food and other cultural preferences emerge from social-class differences, and between the tensions and contrasts among groups in complex societies in the context of global coffee culture, "starbucksization" coffee is able to hegemonize the world's coffee culture to build a new social structure [32].

Together with the society's acceptance of this new lifestyle, coffee shop business adopting the western way of processing coffee start developing in the 1990s. Coffee community activists start opening commercial shops such as in Jogjakarta, Medan, Surabaya, Malang, and Makassar. At the previous era, a coffee shop is an unpopular business and even considered as lower-middle-class business. Coffee becomes a lifestyle of the middle class, for both men and women; therefore it becomes market share besides instant coffee. The modern coffee shop format strongly supports today's increasingly autonomous workers due to the rapid, "self-employed" digital transformation that makes formal offices less likely to play the role of an alternative office [33].

Until the early 2000s, coffee cover was not interesting anymore for mainstream media due to the increase of rating for reality show program in television. Coffee as a new lifestyle of middle class has always risen in the ratings that encourage large publication from mass media in late 2015. "Filosofi Kopi I" or Coffee Philosophy I, is a film that tells the story of a struggle of a local coffee shop providing education about the knack of coffee knowledge to customers. which Its 2015 release was in demand by 231,339 people. In the next two years, until this article was written in August 2017, " Filosofi Kopi I " or Philosophy II was able to obtain up to 250,000 viewers across Indonesia in just one week. It exhibits coffee and all the identity attached to it has obtained its own place in the young generation of Indonesian middle class. Not only as social symbol, but coffee is also a leisure activity providing "leisure time" effective where the coffee shop is used as a location to chat, conversation, friendship and sharing (Argan, et al., 2015; Bursa, 2016; Said, 2012). Furthermore, the coffee shop has developed

2 Based on the data from the USDA Foreign Agricultural Services, Indonesian coffee production is expected to increase from 10.6 million bags green bean equivalent (GBE) in MY 2016/17 to 10.9 million GBE in MY 2017/18. At the same time, post expects Indonesian coffee consumption to grow from 3.32 million bags GBE in MY 2016/17 to 3.4 million bags GBE in MY 2017/18 due to Indonesia's expanding middle class, and their growing taste for coffee[60]. 
not only as a hangout for a new ambiance but also as an alternative to an increasingly autonomous middle class. Oldenburg (1989) describes, "Third places counter the tendency to be restrictive for the enjoyment of others by being open to all and by laying emphasis on qualities not confined to status distinctions current in the society."

This new drinking coffee culture brings the theme of "pure coffee" or "single origin coffee" known as specialty coffee, the new concept promoted by coffee lover community that has brought this new culture to become part of the young and middle-class citizen culture. Clearly, specialty coffee businesses segment consumers by adding new values to the character of specialty coffee drinkers with "ethical" coffees, from simply consuming regular coffee (Morris, 2013: 882-883; Pendergrast, 2010:308-309; Roseberry, 1996). In the case of Starbucks, social media can be a powerful strategy to raise consumers to be their part in building coffee knowledge [39], [40]. Coffee shops have always been a medium for spreading new cultures and building identities almost everywhere in the world either forming new identities, opposition to dominant cultures, or ethnic identities such as the Jewish community in Budapest (Marry, 2013), the lifestyle of the 19th century Turkish society (Argan, et al., 2015; Dana Sajdi, 2014) or lifestyles in modern Japanese society [21]. So, food has transformed from a physical need to a recreational need, has even become a social symbol for the audience [42]. Coffee culture has become popular because it develops quickly and siphons audience attention. It was originally born from the aspirations of individuals to possess new status symbol without the creation of a massive image developed by mass media [43], [44].

Coffee shop design and atmosphere offered is actually more likely to adopt traditional drinking coffee habits. Model of tables and chairs, complimentary food, and order and payment style mostly use traditional coffee shop models. Despite dissimilarities, this phenomenon fits perfectly with the concept of culture jamming [45] and resistance involves the role of emotion [46]. Local shopkeepers actively build resistance values with dominant stores both distinguish physical touches such as layout and coffee shops designs but also build consumer awareness against Starbucks cultural dominance. At the same time, development of these new models coffee shops is slowly shifting traditional drinking coffee culture. So far, local community only knows one way to drink coffee, namely "tubruk" (coarse coffee grounds are boiled along with solid sugar) ${ }^{3}$. Colonialism through private company companies supported by the colonial government exploit the colonized countries by monopolizing the sector that gives the greatest added value of transportation, distribution, and frying so that coffee is not free circulating into local economic commodities, so culture associated with coffee, especially coffee-based local culinary is not developed, including other coffee-related matters [47].

The Starbucks-style drinking coffee culture is massively and systematically cultivated among Indonesia's middle class through various channels. In addition to educating, this customization is also able to create productive social space for cultural growth and coffee business as well. NGOs simultaneously develop alternative coffee marketing networks while encouraging local coffee cultures to grow and flourish as traditional network marketing as monopolistic antithesis [48].

\footnotetext{
3 Since colonial times, local knowledge of coffee has not developed at all. Drinking coffee is just a routine without a touch of culture let alone industry. This is further exacerbated by the culture of instant coffee that encourages the pragmatism of coffee lovers. Consumed coffeein Indonesian community is coffee that has been mixed with corn or rice with the ratio of $3: 1$.
} 
Drinking coffee at mall or shopping centers becomes a new lifestyle of Indonesia's middle class, especially in the big cities pioneered by students and scholars. Business meetings or just treating friends are done in famous coffee shops because they are considered practical and strategic. Coffee was a complimentary drink at food stalls, but now it is the main course and food is a distraction. Starbuck-style coffee became an integral part of the lifestyle of young people and the middle class as part of their leisure time and even institutionalized into a new lifestyle among them. Argan et al (2015) expressed the same incident in Turkey where coffee has a leisure dimension for society in addition to other social functions.

New rich of Indonesia' middle class who are characterized by consumptive culture will indeed pursue the new sensation. An extremely successful commodification built by Starbucks functions to get not only taste of drinking coffee but also symbol of social status. New sensations of coffee are continuously created until drinking coffee culture became part of middle-class lifestyle and characteristics of newly rich. It is a precise marketing strategy to take a very large market niche of the population of 250 million inhabitants with economic growth over $5 \%$ last ten years. Thus, in this context, "starbucksization" is the process of introducing modern and instant coffee shop to the middle-class community. Simultaneously, Starbucks around the world is able to build a new lifestyle for young people so it can shape a special market segment namely, young people. Social space is so quickly built due to social media's role so the culture of drinking coffee is no longer considered peripheral culture.

Popular culture described as "Jeaning America" is jeans transformation process from cowboy archetype into a popular outfit for all classes, from artist to working class by changing jean from social category to social meaning [49]. In the case of coffee in Indonesia, its popularity really finds momentum among young people as a consumptive middle class by making them a symbol of a new lifestyle. The popularity of coffee developed by the local community, although adopting the technology of processing and serving, based on Starbuck style, is increasingly a threat to companies that have been monopolizing the coffee business so they are actively sponsoring various coffee festivals. Coffee that was born from this local community became a popular culture that was born as a form of resistance to the domination of mass culture of companies that have been framing coffee as mass, instant, cheap and practical products become more "human" or cultured, have the values of nobility, fairness where the price is not the size.

\subsection{Local Coffee Shop Resistance}

\subsubsection{Create Border: We Promotes Fairness}

In the 2000s, local coffee shops opened by coffee lovers who vulgarly declared anti-instant coffee and international coffee shop brand certainly Starbuck become a place to spread the seeds of cultural resistance and business network as well which then booming this day ${ }^{4}$. This phenomenon describes as the process of "hegemonic brandscape" as an alternative concept to fill the gap of glocalization or creolization theory where starbucksization gave birth to counter-culture/resistance and not just the process of cultural hybridization [50]. The first form of resistance from local coffee shop owners is the selection of the equivalent word for coffee shop. Local coffee shop identifies its stalls as "kedai"

\footnotetext{
${ }^{4}$ Starbucks has grown to 240 retail outlets in Indonesia since 2002, while Maxx has grown to 70 outlets since opening in 2015.
} 
referring to the term "kedai kopi" in Sumatra especially Aceh, rather than café that is generally pinned by Indonesian to the coffee shop like Starbucks. "Kedai" has more informal and free meaning, while cafés tend to be formal and tied. In addition to the resistance to the term, the choice of the name fits perfectly with the characteristics of consumers who tend to like a free and informal style than cafés that are considered rigid. In the circle of coffee shop owner, there are also various resistance terms such as "kopi itu digiling bukan digunting (coffee is ground not cut)", "kopi opo njagung (drinking coffee, not corn)", "rasa kopi selalu jujur (coffee taste is always honest)". "Kopi digiling bukan digunting" is a hint for instant coffee lovers. Coffe shop owners always advise to use original coffee bean being "ground" directly and do not recommend consuming coffee from sachets that are "cut" because they are considered bad. "Ngopi opo njagung" is a form of satire on consumers of instant coffee that is always socialized.

Simultaneously the symbols of resistance to this dominance reinforce the phenomenon of connoisseurship consumption community (Manzo, 2010 and Quintão et al, 2017) where coffee lovers continue to seek coffee with better quality and variety of origin that almost impossible can be provided by companies with mass production methods such as Starbucks. The local coffee shop smartly uses this gap to target fanatic consumers with local coffees not provided by Starbucks and similar stores. Thus, on the cultural side, local coffee shop perform a Deconstruction process of business value from "full of secrets" to be "honest and open". This phenomenon is in line with Grinshpun research (2014) in Japan that "strarbucksization" is able to inform the public about the global coffee culture in smart method but Japaneselocal business institutions are able to build the image that people have their own way to express their coffee culture.

Ethic issues are also the concern of shop owners as well as the community of coffee lovers by labeling that the coffee they sell should be fair. The issue of price disparity at the farmers' level with the price at coffee shop level becomes the owner's focus. A network of coffee shops and coffee lover communities in big cities is active enough to educate market on the principle of fairness in drinking coffee. Best quality coffee is not always expensive; they consider that commercialization of coffee by modern coffee shop is unfair. Thus, local coffee shops always state that the best coffee should also be drunk by everyone at and the price should be affordable for the average income of middle class. Coffee should be drunk not only by the rich but also the poor. Why? According to the coffee shop owners, it would be unfair to have a cup of coffee at Starbuck at $\$ 4$ while the best green bean coffee will cost only $\$ 3$ per kilogram at farmer level. That's why, local coffee shop community terms the behavior of modern coffee shop owner like struck as a business vampire or "sucking blood" of farmers ${ }^{5}$.

Local shop owners insist that tradability of coffee bean is important not only to preserve the flavors as the reason for the modern coffee shop but also as transparency to the consumer. For local coffee shops, explaining where the coffee beans comes from and how the processing model becomes an obligation. Norm developing among local shop owners is that the more traceable the origin of coffee is, the higher reputation the coffee has. In fact, some of the coffee shops attach photographs of coffee farmers as a decoration in the shop and on packaging as a form of appreciation to the farmers.

\footnotetext{
5 The image is developed based on the experience of the coffee shop owners and coffee consumer community who once were members of organizations concerning on environmental sustainability and social justice.
} 
Fair coffee and health benefits campaigns when consuming traceable and qualified coffee help store attract new and old customers to not only use altruistic considerations in purchasing farmer's products but also on pragmatic "health and quality" considerations. This is in line Davies' research (2016) which stated consumer motivation is leaned towards individualistic and social identity-driven than altruism considerations (Araque-Padilla, et al., 2015; Davies \& Gutsche, 2016).

Additionally, they build an issue of coffee bean monopoly by large coffee so buying coffee bean to the big traders who are considered monopolizing coffee means being unfaithful to friends. Although not being consumers' major consideration in choosing coffee shops, based on Davies and Gutche research (2016), the image becomes the easiest differentiator between ordinary coffee shop and local coffee shop. However consumers still have a good attention on product ethics even though their membership in social groups does not have a direct impact on one's shopping choices[52]. These local coffee shop networks are proven to be very effective to maintain continuity of coffee supply and coffee bean quality. This network is also a medium to share information on business and "resources sharing" which improve the efficiency of the coffee shop business. From marketing perspective, the local coffee-shop pattern in network building is part of building shop reputation that always keeps the purity of the coffee beans so that they do not arbitrarily take from the unknown factors in their network.

\subsubsection{Building Identity: We locally and Origin}

Local coffee business player's resistance to the culture and mainstream coffee business such as Starbucks is not limited to coffee shop management strategy or cultural resistance. They go further by developing a supply network of raw materials, especially green beans; they no longer worked with traditional coffee collectors "middlemant" but they go directly to the farmers. Although it is still sporadic, the direct connection between the coffee shop owners and the farmers became a source of alternative market information among them. This phenomenon increasingly shows the seriousness of local shops to set the difference between local and international coffee shops by degrading the dominance of global brands as anti-Starbuck Brandscape of Arsel (2014). The store uses a direct relationship with farmer as a capital building image in addition to ensuring the availability of a continuous and quality coffee bean throughout the year. In addition, the new marketing network according to some of our key informants increased the competition of local traders, therefore, the price of coffee beans continued to improve over the last five years. Farmers' participation in alternative coffee markets such as organic coffee and fair trade networks has decreased the vulnerability of household livelihoods in several coffee-producing countries [53], [54].

Co-creation of knowledge process indirectly happens on social interaction is related to post-harvest handling of coffee. Learning patterns that occur in the alternative network is able to create a knowledge reproduction cycle that proves to be very helpful for innovation (Peschl \& Fundneider, 2012; Medema et al,. 2017). Post-harvest coffee knowledge also quickly spreads to farmers who establish relationships with the store because the store is interested in good quality products; therefore, they transfer the knowledge to farmers. For instance is in Malang, there is an association of coffee farmers who develop networks with more than 100 local shops throughout Indonesia. They even build their brand of coffee production to be distributed to local shops, so they get a better price. 
Regular meetings are held to accommodate coffee shops complaints while they provide input both price and improvements on farmer-level processing 6 .

This coffee shop relationship becomes a new chapter for the supply chain coffee that was closed because of the control by a network of certain traders since the colonial era. Although the number of transactions is small, marketing network developed is relatively strong because the profit margin offered is quite large compared to using conventional marketing network. So far, super-quality coffees have only one-third of the international market so the fixed price accepted by farmer becomes extremely low. Entry of coffee shops to the farmer directly causes the price to be relatively better because the shop would give higher prices as they direct sell coffee to consumers. At the same time, by building the image that the coffee they serve to customers is fresh and directly obtained from partner farmers, they are able to build the shop reputation in providing origin coffee. This is very important for coffee shops in Indonesia. Coffee beans are easily accessible in traditional markets, and therefore special distinction is required between the original and non-original one.

\section{Discussion}

Drinking coffee culture in Indonesia is different from the coffee culture developed in other countries such as Japan or Europe that fully adopt Starbucks style. Usually, drinking coffee in the West is introduced by business community and then become a lifestyle, while in Indonesia it is developed by group of environmentalists and coffee lovers into business. As we know, most of the environmentalist has sensitivity to the issues of exploitation and injustice both natural and social justice issues. The activists of local coffee shop built a differentiating wall so that the polarization of images where Starbuck and similar stores were considered to capitalize coffee into a mere business commodity, while the local shop was a symbol of the coffee social vision. Reflecting on the above phenomenon, drinking coffee culture of Indonesia's middle class is now a process of social identity formation that is strongly influenced by the local coffee culture although influenced by pop culture certainly starbuck style. Indonesia's middle class does not necessarily follow a new culture, but it rearticulates the culture into a cultural form with a new localized characteristic of identity.

Instead of adopting western culture as in the case of McDonald in Russia [20] coffee shops in Japan [21], and other countries in Europe, Indonesia's middle class develops a new coffee culture as a form of resistance to pop culture. They do not want to call their coffee store "Café" or "coffee shop", but choose the term "kedai," a term more rooted in local custom but has not too traditional meaning like warkop or coffee stall. The term "kedai" is a form of resistance to modern coffee shop brands such as Starbucks, Kopitiam, Exelco, and others because "kedai" means freedom and brotherhood while café seems formal and commercial. Thus, local communities have a special way of responding to outside cultures rationally, not merely fighting or adopting but more than that articulating them into a more functional culture for them as a cultural liquidity [57].

Local coffee shops not only establishes a different identity from Starbucks-style coffee culture, but local shops also build up the values of resistance to the domination and monopoly of modern coffee shop. Resistance slogans installed on their stores also became social media fan pages showing the identity of the coffee shop position in the business pattern developed by modern coffee shop.

\footnotetext{
${ }^{6}$ Currently local coffee stores that have sufficient financial ability compete against one another to develop micro lots along with local residents. Their average production is between 2 and 5 tons in which their products are sold in their own shops or distributed to their network stores.
} 
Coffee is not just a commodity but also a social media where the monopoly over coffee, both business and standardization by a conglomeration is a form of injustice. This value is developed by coffee shop community even though in practice of processing and serving they adopt a bit of modern coffee shop technology. This phenomenon is an incorporation and exclusion process through which local culture differentiating by providing label on local food as "our," "authentic," "national," or "regional" (the Self), in distinction from "their," "artificial," or "international" (the Other) [58]. At the same time, local coffee shops are self-taught or learn coffee knowledge on international coffee associations such as SCAE or SCAA. Quality standards of coffee beans, processing techniques and the way to brew adopt the techniques introduced by international coffee associations. The ways they choose to develop knowledge of coffee entirely adopt the western coffee culture, but in packing into business, they are entirely at odds with the way and business philosophy of Starbuck and other modern coffee shops. Local coffee shop establishes a coffee learner community by building closer relationship between business owners and customers not only in maintaining loyalty but also spreading views on fair business principles.

Patterns of relationships built between coffee shops and farmer groups are also part of their antithesis on a network of unfair coffee marketing. Although the number of their needs is not large yet, several coffee shops, especially those with enough capital start stocking coffee beans if the harvest is not good or the price is too expensive. This formation of coffee culture like Japan is decribed as part of participation in the global value chain of coffee along with the culture and accompanying culture [59]. In Indonesia's case, it shows different patterns leaning towards more "autonomous" because local coffee shops can obtain coffee bean directly from farmers. Looking at the pattern of development of the coffee community in Indonesia, creolization phenomenon apparently cannot fully describe the dynamics, especially the resistance to the establishment of the global coffee culture. If creolization is a fusion process from different cultures to new forms, but drinking coffee culture in Indonesia that always highlights the efforts of cultural deconstruction is a symbol of resistance rather than a business symbol. Such a view has institutionalized to be part of the reference values of the coffee lover community and the owners of the coffee shops.

\section{Conclusions}

This article illustrates how the local coffee culture responds to popular culture introduced by Starbucks and similar coffee shops in the last five years, or whether it is following the same pattern of creolization or domestication as in other parts of the world or following other directors or not. As a coffee-producing country that has an indigenous culture and is relatively independent of global coffee supply, it seems that local coffee shops perform selection of global elements by accentuating local characteristics so that it becomes a kind of encapsulation process due to the elements of resistance in the global culture. Thus, for several aspects, local coffee culture does not fully adopt the western culture, especially in the product standardization, processing techniques, and coffee-based beverage menus. While for business culture they develop more localized styles by improving small and simple "warkop" or coffee stall becomes a relatively modern but localized "kedai". In addition, consumers and coffee activists also develop fair business value in opposition to the Starbucks philosophy they consider exploitative. Consumers are not only seen as business objects but are part of the coffee business chain and thus are responsible for the development of a more just coffee business. 
If you look at the phenomenon, the domestication of Starbucks-style drinking coffee culture applies only to technology adoption and seed quality, while the business model from the value offered to how to build a coffee shop is very different. Consumers are just overwhelmed with the view that if you drink coffee at Starbucks then you get the best taste and quality of coffee, which then anticipated by local coffee shop that drinking coffee is not only a taste but also fair. Thus, local coffee consumers are more likely to "resist" mainstream values developed by international coffee shops rather than forcing local coffee shops to follow them. So, the booming coffee culture among Indonesia's middle class is a thing that deviates from the customs in other countries such as Japan, China, and European countries. Although not rapidly growing, the local coffee culture still seems to dominate and even articulate the local coffee business. If we observe the big cities in Indonesia, growth of international stores such as Starbucks is not as quick as other franchises like MC Donald or California fried chicken (CFC).

Indonesia's middle class prefers to follow the local way of adopting the international way in a small part of its element. Despite being able to attract middle-class consumers and withstand the pace of international coffee shops, growth of drinking coffee culture driven by local coffee shop remains difficult to develop when it reaches a certain level. Why? Because it depends on community, then market segmentation becomes narrow because most people will feel less comfortable. So they will be able to live and grow only to a certain level not to be as big and stingy as Starbucks -we call this phenomenon as a process of encapsulation rather than creolization or domestication.

Author Contributions: Conceptualization, methodology, validation, formal analysis, and investigation were conducted by (Y.Y.). It involved resources, data curation, and writing process - original draft preparation. (M. P.) contributed on writing process - review and editing, visualization, and investigation.

Funding: This research was funded by Brawijaya University Research Fund and have received no external funding.

Acknowledgments: The authors extend their gratitude for the Indonesia Ministry of Higher Education and Research and Brawijaya University Research Fund for granting research funds and grants.

Conflicts of Interest: The authors declare no conflict of interest

\section{References}

[1] D. Grigg, "The worlds of tea and coffee: Patterns of consumption," GeoJournal, vol. 57, no. 4, pp. 283294, 2002.

[2] J. Neilson, "Institutions, the governance of quality and on-farm value retention for Indonesian specialty coffee," Singap. J. Trop. Geogr., vol. 28, no. 2, pp. 188-204, 2007.

[3] S. J. Barter, “Coffee: An Indian Ocean Perspective," pp. 61-81, 2016.

[4] Jhon M. Talbot, "The struggle for control of a commodity chain: Instant Coffee from Latin America," Lat. Am. Res. Rev., vol. 32, no. 2, 1997.

[5] C. M. Tucker, Coffee Culture: Local Experiences, Global Connections. New York: Routledge, 2012.

[6] L. Drummond, “The Cultural Continuum: A Theory of Intersystems," Man, vol. 15, no. 2, pp. 352-374, 1980.

[7] J. Chaplin, "Creoles in British America: From Denial to Acceptance," in Creolization : History, Ethnography , Theory, 2007.

[8] Charles Stewart, "Creolization: History, Ethnography, Theory," in Creolization: History, Ethnography, Theory, C. Stewart, Ed. 2007, pp. 1-25.

[9] L. a. Wilkie, "Culture Bought: Evidence of Creolization in the Consumer Goods of an Enslaved 
Bahamian Family," Hist. Archaeol., vol. 34, no. 3, pp. 10-26, 2000.

[10] R. Baron and A. C. Cara, "Introduction: Creolization and Folklore: Cultural Creativity in Process Introduction: Creolization and Folklore," J. Am. Folk., vol. 116, no. 459, pp. 4-8, 2003.

[11] V. Munasinghe, "Theorizing world culture through the New World: East Indians and creolization," $A m$. Ethnol., vol. 33, no. 4, pp. 549-562, 2006.

[12] S. Palmié, “Creolization and Its Discontents," Annu. Rev. Anthropol., vol. 35, no. 1, pp. 433-456, 2006.

[13] H. M. Simpson, “"Is all o' we one?”: Creolization and ethnic identification in Samuel Selvon's 'Turning Christian,"” J. Commonw. Lit., vol. 0021989416, pp. 1-3, 2016.

[14] L. Tibere, "Food as a factor of collective identity: The case of creolisation," French Cult. Stud., vol. 27, no. 1, pp. 85-95, 2016.

[15] Marwan M. Kraidy, “The global, the local, and the hybrid : A native ethnography of glocalization," Crit. Stud. Mass Commun., vol. 16, no. 4, pp. 456-476, 1999.

[16] M. Doshi, “Elmo everywhere: A critical analysis of glocalization,” Teach. Media Q., vol. 5, no. 1, 2017.

[17] B. Wellman, “Little Boxes, Glocalization, and Networked Individualism From Little Boxes to Social Networks," Digit. Cities, pp. 10-25, 2002.

[18] Roland Robertson, “Glocalization: Time-Space and Homogeneity-Heterogeneity,” in Global Modernities, S. L. \& R. R. Mike Featherstone, Ed. 1995.

[19] V. Roudometof, Glocalization: a critical introduction, vol. 3, no. 2-3. London and New York: Routledge, 2016.

[20] M. L. Caldwell, “Domesticating the French Fry: McDonald's and Consumerism in Moscow," J. Consum. Cult., vol. 4, no. 1, pp. 5-26, 2004.

[21] H. Grinshpun, "Deconstructing a global commodity: Coffee, culture, and consumption in Japan," J. Consum. Cult., vol. 14, no. 3, pp. 343-364, 2014.

[22] I. A. Davies and S. Gutsche, “Consumer motivations for mainstream 'ethical' consumption," Eur. J. Mark., vol. 50, no. 7/8, pp. 1326-1347, 2016.

[23] M. Purnomo, P. Daulay, M. R. Utomo, and S. Riyanto, "Moderating Role of Connoisseur Consumers on Sustainable Consumption and Dynamics Capabilities of Indonesian Single Origin Coffee Shops," Sustain., vol. 11, no. 5, pp. 1-17, 2019.

[24] M. Pope, "Career counseling in the twenty-first century: Beyond cultural encapsulation," Career Dev. Q., vol. 52, no. 1, p. 54, 2003.

[25] P. P. Heppner, K. T. Wang, M. J. Heppner, and L.-F. Wang, “From cultural encapsulation to cultural competence: The cross-national cultural competence model.," in APA handbooks in psychology. APA handbook of counseling psychology, Vol. 2. Practice, interventions, and applications, 2012, pp. 433-471.

[26] L. Al-Rasheed, Madawi; Al-Rasheed, “The Politics of Encapsulation: Saudi Policy towards Tribal and Religious Opposition," Middle East. Stud., vol. 32, no. 1, pp. 96-119, 1996.

[27] J. S. Duncan, "Embodying colonialism? Domination and resistence in nineteenth-century Ceylonese coffee plantations," J. Hist. Geogr., vol. 28, no. 3, pp. 317-338, 2002.

[28] V. Saravanan, "Colonialism and coffee plantations: Decline of environment and tribals in Madras Presidency during the nineteenth century," Indian Econ. Soc. Hist. Rev., vol. 41, no. 4, pp. 465-488, 2004.

[29] S. Topik, "Trade History: From the Tree to the Futures Market, the Historical Process of Coffee Commodification, 1500-Today," in Beyond Free Trade Alternative Approaches to Trade, Politics and Power, K. Ervine and G. Fridell, Eds. International Political Economy Series, 2015, pp. 17-18.

[30] T. Clark, Starbucked: A Double Tall Tale of Caffeine, Commerce, and Culture. New York: Little, Brown, 2007. 
[31] R. W. Jamieson, “The Essence of Commodification: Caffeine Dependencies in the Early Modern World," J. Soc. Hist., vol. 35, no. 2, pp. 269-294, 2001.

[32] P. Bourdieu, Distinction: A social critique of the judgement of taste. Harvard university press, 1984.

[33] J. Morris, “Why espresso? Explaining changes in European coffee preferences from a production of culture perspective," Eur. Rev. Hist., vol. 20, no. 5, pp. 881-901, 2013.

[34] I. Said, “Coffee Shops and Modern Life Style in Makassar, Indonesia." NIU 2012 Sandwich-like Fellows Working Papers, 1-16., 2012.

[35] E. Argan, Metin, Akyildiz, Muge, Burcu, Ozdemir, Bas, Avsar, Akkus, "Leisure Aspects of Turkish Coffee Consumption Rituals: An Exploratory Qualitative Study," Int. J. Heal. Econ. Dev., vol. 1, no. 1, pp. 26-36, 2015.

[36] N. Bursa, “Brewing Pots of Revolt : Coffeehouses,” 2016.

[37] W. Roseberry, "The Rise of Yuppie Coffees and the ReiMagination of Class i n the United States," Am. Anthropol., vol. 98, no. 4, pp. 762-775, 1996.

[38] M. Pendergrast, Uncommon Grounds : How It Transformed Our World. New York: Basic Books, 2010.

[39] A. Y. K. C. and S. Banerjee, “Customer Knowledge Management via Social Media: The case of Starbucks," J. Knowl. Manag., vol. 17, no. 2, pp. 237-249, 2009.

[40] Ch. Yin Sam and Y.Cai, "A Study on the Use of Social Media to Understand Consumer Preference : The Case of Starbucks," Int. J. Manag. Bus. Res., vol. 5, no. 3, pp. 207-214, 2015.

[41] Dana Sajdi, "Decline, its Discontents and Ottoman Cultural History: By Way of Introduction," in Ottoman Tulips, Ottoman Coffee: Leisure and Lifestyle in the Eighteenth Century, D. Sajdi, Ed. 2014, pp. 1-40.

[42] C. Fischler, "Food, self and identity," Soc. Sci. Inf., vol. 27, no. 2, pp. 275-292, 1988.

[43] D. Strinati, 0 Resensi Tulis resensi An Introduction to Theories of Popular Culture. Routledge, 2004.

[44] J. Storey, Cultural Theory and Popular Culture: An Introduction. Routledge, 2015.

[45] V. Carducci, “Culture Jamming,” J. Consum. Cult., vol. 6, no. 1, pp. 116-138, 2006.

[46] J. A. Sandlin and J. L. Callahan, “Deviance, Dissonance, and Détournement," J. Consum. Cult., vol. 9, no. 1, pp. 79-115, 2009.

[47] G. Dicum, “Colony in a Cup,” Gastronomica, vol. 3, no. 2, pp. 71-77, 2003.

[48] G. Dierberger, M. Mcintosh, and N. Johnson, “Java Plus Coffee : A Case Study in Economic Sustainability in a Non-Profit Organization," vol. 16, no. Exhibit 3, pp. 65-81, 2016.

[49] J. Fiske, Understanding Popular Culture. Routledge, 2010.

[50] C. Thompson and Z. Arsel, "The Starbucks brandscape and the discursive mapping of local coffee shop cultures," J. Consum. Res., no. October, 2004.

[51] R. A. Araque-Padilla, M. J. Montero-Simó, P. Rivera-Torres, and C. Aragón-Gutiérrez, “Moderating the Relationship Between Price and Perceived Value of Ethical Products," J. Agric. Environ. Ethics, vol. 28, no. 2, pp. 217-230, 2015.

[52] J. Gummerus, V. Liljander, and R. Sihlman, “Do Ethical Social Media Communities Pay Off? An Exploratory Study of the Ability of Facebook Ethical Communities to Strengthen Consumers' Ethical Consumption Behavior," J. Bus. Ethics, vol. 144, no. 3, pp. 449-465, 2017.

[53] C. Bacon, "Confronting the coffee crisis: Can Fair Trade, organic, and specialty coffees reduce smallscale farmer vulnerability in Northern Nicaragua?," World Dev., vol. 33, no. 3, pp. 497-511, 2005.

[54] M. Wollni and M. Zeller, “Do farmers benefit from participating in specialty markets and cooperatives? The case of coffee marketing in Costa Rica," Agric. Econ., vol. 37, no. 2-3, pp. 243-248, 2007.

[55] M. F. Peschl and T. Fundneider, "Spaces enabling game-changing and sustaining innovations: Why 
space matters for knowledge creation and innovation," Organ. Transform. Soc. Chang., vol. 9, no. 1, pp. 41-61, 2012.

[56] A. W. and N. M. Wietske Medema, Jan Adamowski, Christopher Orr, Alison Furber, “(/journal/water)," Water, vol. 9, no. 1, 2017.

[57] B. S. Turner, “McDonaldization: Linearity and Liquidity in Consumer Cultures," Am. Behav. Sci., vol. 47, no. 2, pp. 137-153, 2003.

[58] P. Scholliers and A. Geyzen, “Upgrading the Local Belgian Cuisine in Global Waves," Gastron. J. food Cult., vol. 10, no. 2, pp. 49-54, 2010.

[59] H. Grinshpun, “The Drink of the Nation? Coffee in Japan's Culinary Culture," in Feeding Japan: The Cultural and Political Issues of Dependency and Risk, Palgrave Macmillan, Cham., 2017, pp. 167-190.

[60] T. Wright and A. Rahmanulloh, “Indonesia Coffee Annual Report 2016.” USDA-Foreign Agricultural Service, 2016. 